\title{
STRATEGI KOMUNIKASI POLITIK DPD PARTAI GOLKAR PADA PEMILU LEGISLATIF ACEH TENGAH 2019
}

\author{
Hasan Basri \\ hasangayo15@gmail.com \\ Universitas Gajah Putih. Indonesia
}

\section{Article Info}

Keyword:

political communication, golkar

party, legislative election

\begin{abstract}
This research focuses on the political communication strategy of the Golkar DPD in the 2019 Central Aceh legislative elections. A political communication strategy is very important for a political party that wants to attract sympathy to get people's approval. This study adopts a qualitative approach that describes and explains the political communication strategy of the Golkar legislative electoral council. Golkar as one of the parties involved in the competition and winning the 2019 Central Aceh Pilkada won four DPRK seats. The political communication strategy carried out by Golkar in winning the 2019 Election is for Golkar to listen to and convey the aspirations of the people. The political communication strategy implemented by the Golkar party in the legislative elections is structured communication from the central leadership to cadres in rural areas so that political messages can be conveyed equally, in the face of the 2019 legislative elections, Golkar provides information to people who have the right to vote, educate the public, accommodate the aspirations of the community, and socializing aimed at the government and other political institutions, the board of DPD Golkar to convey all forms of work programs to the public, as a means of party political communication such as providing information to the mass media. People who do not receive messages and do not want to communicate with Golkar party cadres because they are not interested in political activities, people who are more interested in political manipulation, and people who already have candidates from close relatives.
\end{abstract}

Copyright (C) 2021 Interaksi: Jurnal Ilmu Komunikasi. All rights reserved.

\section{PENDAHULUAN}

Negara Indonesia adalah salah satu negara demokrasi yang menghendaki adanya pemilihan umum secara langsung, baik dalam pemilihan umum memilih presiden, anggota legislatif dan kepala daerah. Negara Republik Indonesia adalah negara yang berkedaulatan rakyat dengan berdasar kepada Pancasila. Pada Pasal 1 ayat (2) UUD Negara Republik Indonesia tahun 1945 menyatakan "Kedaulatan berada di tangan rakyat dan dilaksanakan menurut Undang-Undang Dasar". Sehingga Pasal 22E ayat (2) UUD 1945 menegaskan "Pemilihan umum diselenggarakan untuk memilih anggota Dewan Perwakilan Rakyat, Dewan Perwakilan Daerah, Presiden dan Wakil Presiden, dan Dewan Perwakilan Rakyat Daerah. Pemilihan umum (Pemilu) yang diselenggarakan oleh suatu Komisi Pemilihan Umum yang bersifat nasional, tetap, dan mandiri, serta dilaksanakan setiap lima tahun sekali itu merupakan wujud sirkulasi pemberian mandat baru oleh rakyat kepada wakil-wakilnya di lembaga legislatif dan kepada Presiden dan Wakil Presiden sebagai manifestasi dari kedaulatan rakyat. Konsekuensi dari berubahnya sistem Pemerintahan adalah berubahnya fungsi dan hubungan lembaga-lembaga tinggi negara, khususnya antara Eksekutif dan Legislatif.(Syamsuddin Haris, dkk 2014: 6)

Pemilihan umum merupakan sarana persaingan antara beberapa partai politik yang ada di Indonesia. Pemilihan umum legislatif 2019 yang dilaksanakan di Aceh Tengah diikuti oleh banyak partai politik yang berimplikasi pada ketatnya persaingan antar partai politik dalam perebutan suara pemilih.

Segala strategi, taktik, dan cara dilakukan oleh semua partai politik untuk memenangkan pemilu ini. 
Secara umum Pemilu Legislatif di Kabupaten Aceh Tengah yang diikuti banyak partai politik. Partai Golkar adalah salah satu partai politk yang ada dalam jajaran partai politik di dalam pemilihan umum Legislatif di Aceh Tengah 2019.

Sebagai salah satu partai politik yang mempunyai nama besar Partai Golkar juga mempunyai peranan dalam menyampaikan pesan politik kepada simpatisan dan masyarakat, bergerak dalam lapangan politik untuk ikut mengatur ketatanegaraan. Strategi komunikasi politik yang digunakan harus tepat sasaran sehingga perolehan suara yang didapat akan sesuai dengan yang diinginkan. Pemenangan Pemilu legislatif 2019 merupakan agenda utama yang memerlukan penyusunan strategi dan langkah-langkah secara sistematis dengan program yang jelas dan terukur. Strategi politik adalah strategi yang digunakan untuk merealisasikan cita-cita politik. Kajian strategi politik, merupakan suatu analisis tentang bagaimana proses yang terjadi di dalam pemenangan dalam satu pertarungan politik oleh partai politik, atau secara langsung, oleh seorang calon legislatif atau calon pimpinan daerah, yang menghendaki kekuasaan dan pengaruh sebesar-besarnya di tengah-tengah masyarakat.

Berbagai partai politik menjadikan proses politik menjadi lebih berdinamika, yang diwarnai oleh pertarungan antar partai yang sangat terbuka, hingga akhirnya dibutuhkan adanya strategi politik untuk memenangkan hati dan meraih simpati masyarakat sebagai dengan menggunakan berbagai pendekatan komunikasi yang baik pada masyarakat. Komunikasi adalah hubungan kontak antar dan antara manusia baik individu maupun kelompok. Komunikasi adalah inti semua hubugan sosial, apabila orang telah mengadakan hubungan tetap, maka system komunikasi yang mereka lakukan akan menentukan apakah system tersebut dapat mempererat atau mempersatukan mereka, mengurangi ketegangan atau melenyapkan persengketaan apabila muncul.(Widjaja, 2008:1) Fenomena komunikasi dan fenomena politik, baik komunikasi dan politik sebagai serbahadir (ubiquitous) dimaknai komunikasi dan politik itu berada di manapun dan kapan pun juga. Karena setiap orang berkomunikasi dan berpolitik. Maka dalam rangka menjelaskan hubungan antara komunikasi dan politik dapat diuraikan, memandang gejala komunikasi sebagai variabel bebas (independent variable) yang justru menjadi penyebab bagi gejala politik, seperti bagaimana pers di negara-negara maju punya andil besar dalam mempengaruhi pengambilan keputusan politik. (Arifin, 2003: 24).

Strategi komunikasi politik sangatlah penting dalam mendapatkan suara pada Pemilu legislatif. Untuk mendapatkan simpati masyarakat, fraksi partai Golkar haruslah melakukan hubungan komunikasi yang baik.

Sebagai strategi untuk mendapatkan suara terbanyak untuk pemenangan guna memenangkan partainya, baik melalui pengorganisasian dan konsolidasi kader, melalui komunikasi yang baik. Karena tanpa itu pengaruh dan kekuasaan mustahil diperoleh, maka pada prinsipnya kemenangan dalam Pemilu adalah harga mati bagi setiap Partai politik. Pada Pemilu calon legislatif 2014 partai golkar memperoleh 17,418 total suara. Daerah Pemilhan (Dapil) 1 Golkar memperoleh 4.662. Daerah Pemilhan (Dapil) 2 Golkar memperoleh 4.174. Daerah Pemilihan (Dapil) 3 Golkar memperoleh 3.745. Daerah Pemilhan (Dapil) 4 Golkar memperoleh 4.837. sehingga partai Golkar memperoleh 3 kursi di DPRK Aceh Tengah.(...,KIP, 2014)

Komunikasi Politik sebagai kegiatan politik merupakan penyampaian pesan-pesan yang bercirikan politik oleh aktor-aktor politik kepada pihak lain. Kegiatan ini bersifat empirik karena dilakukan secara nyata dalam kehidupan sosial. Sedangkan sebagai kegiatan ilmiah maka komunikasi politik adalah salah satu kegiatan politik dalam sistem politik.

Secara umum komunikasi politik diartikan oleh Anwar Arifin (2014:57) sebagai pembicaraan dan tindakan untuk memengaruhi manusia dalam kehidupan bermasyarakat dan bernegara. Sedangkan McNair dalam Anwar mengatakan bahwa komunikasi politik adalah komunikasi yang diupayakan untuk mencapai tujuan-tujuan politik tertentu. Namun Plano dalam Anwar mengatakan bahwa komunikasi politik merupakan infrastruktur politik, yaitu suatu kombinasi dari berbagai interaksi sosial dimana informasi yang berkaitan dengan usaha bersama dan hubungan kekuasaan masuk kedalam peredaran. McNair (Anwar, 2014:58)

Berdasarkan pandangan tersebut, jelas bahwa 
komunikasi politik berperan dalam suatu sistem politik, terutama untuk memperlancar pelaksanaan fungsi system politik. Menurut Rochajat dan Sumarno (2006:1014) ada beberapa unsur-unsur komunikasi politik, yaitu: a. Komunikator politik yaitu individu-individu yang menduduki struktur kekuasaan, individu-individu yang berada dalam suatu institusi, asosiasi, partai politik, lembaga-lembaga pengelola media massa dan tokohtokoh masyarakat. Komunikator politik dapat pula berupa negara, badan-badan internasional dan mereka yang mendapat tugas atas nama negara. b. Komunikan dapat bersifat pereorangan, kelompok, dapat berupa institusi, orgaisasi masyarakat, partai politik dan dapat pula negara dan pemerintah negara lain. 1. Isi (pesanpesan) komunikasi merupakan prduk penguasa setelah melalui proses encoding atau setelah diformulasi kedalam simbo-simbol sesuai lingkup kekuasaan. 2. Tujuan komunikasi politik, tujuan komunikasi selalu berimpit dengan tujuan negara. Sifat dan bentuk tujuan yag hendak dicapai akan sangat bergantung kepada sistem politik yang mendasarinya. 3. Sumber-sumber komunikasi politik berasal dari individu karena ideidenya yang sangat berharga, atau dapat pula muncul dari elit politik, dan dapat pula berasal dari suatu paham, ideologi, pola keyakinan, seperangkat norma, kitab suci atau dari dokumen-dokumen yang tersimpan secara terpelihara da lain-lain.

Untuk mencapai sasaran dan tujuan yang telah ditentukan, diperlukan strategi komunikasi politik yang baik dan menarik. Dalam penyampaian komunikasi politik harus bersifat persuasif dan positif. Dibutuhkan perencanaan yang matang dalam penyampaian pesan politik tersebut. Untuk penyebarannya, dibutuhkan para komunikator politik yang mempunyai kemampuan yang baik dalam berbicara agar pesan yang disampaikan dapat dimengerti dan dipahami, sehingga dapat memperoleh respon yang baik dan positif dari masyarakat.

Partai Politik Menurut Budiardjo (2008:404) secara umum partai politik adalah organisasi dari aktivitas-aktivitas politik yang berusaha untuk menguasai kekuasaan pemerintahan serta merebut dukungan rakyat melalui persaingan dengan suatu golongan atau golongan-golongan lain yang mempunyai pandangan berbeda. Secara Khusus Pengertian Partai Politik disebutkan dalam Undang-Undang Republik Indonesia Nomor 31 Tahun 2002 mengenai partai politik, yaitu Pengertian partai politik merupakan organisasi politik yang dibentuk oleh sekelompok warga negara Republik Indonesia secara sukarela atas dasar persamaan kehendak dan cita-cita, untuk dapat memperjuangkan kepentingan anggota, kepentingan masyarakat, bangsa dan negara melalui pemilihan umum. Partai politik disini dimaksud sebagai sebuah organisasi politik yang bertujuan menguasai pemerintahan serta mengendalikan masyarakat dengan cara merebut perhatian rakyat melalui persaingan. Karena Partai politik merupakan perantara yang besar yang menghubungkan kekuatan-kekuatan dan ideologi sosial dengan lembaga -lembaga pemerintahan yang resmi. Fungsi Partai Politik Menurut Budiarjo (2008:405-409) terbentuknya sebuah lembaga tidak pernah terlepas dari fungsi lembaga tersebut, demikian halnya dengan partai politik. Fungsi partai politik antara lain: sebagai Sarana Komunikasi politik, Sebagai sarana Sosialisasi politik, Sebagai sarana rekrutment politik, Pengatur konflik. Di lain sisi, partai politik juga punya tanggung jawab untuk terus memperhatikan situasi dan kondisi masyarakat, sekaligus mengembangkan solusi yang dapat digunakan untuk menyelesaikan masalah di tengah masyarakat. penyelesaian masalah ini biasanya dijawab dengan program politik yang di buat oleh partai.

Strategi politik sebuah rencana yang sistematik dan mengimplementasikannya dalam mencapai tujuan memenangkan dalam bidang politik. Dengan strategi politik inilah partai politik mampu memenangkan dalam setiap momentum perebutan kekuasaan. Strategi Politik itu sendiri merupakan strategi atau tehnik yang digunakan untuk mewujudkan suatu cita-cita politik. Strategi politik sangat penting untuk sebuah partai politik, tanpa adanya strategi politik, perubahan jangka panjang sama sekali tidak akan dapat diwujudkan. Perencanaan strategi suatu proses dan perubahan politik merupakan analisis yang gamblang dari keadaan kekuasaan, sebuah gambaran yang jelas mengenai tujuan akhir yang ingin dicapai dan juga segala kekuatan untuk mencapai tujuan tersebut.

Strategi Komunikasi Politik merupakan 
rencana yang meliputi metode, teknik dan tata hubungan fungsional antara unsur-unsur dan faktor-faktor dari proses komunikasi guna kegiatan operasional antara unsur-unsur dan faktor-faktor dari proses komunikasi guna kegiatan operasional untuk mencapai tujuan dan sasaran. Dalam strategi komunikasi O'Keefe dalam Damsar (2010:10-11) mengajukan dua pedekatan mengenai teori produksi pesan yang disebutnya dengan model "pilihan strategi” (Strategy Choice) dan "desain pesan"(message desain). Model pilihan strategi melihat bagaimana komunikator memilih di antara berbagai strategi pesan untuk mencapai suatu tujuan, sedangkan model desain pesan memberikan perhatiannya pada bagaimana komunikator membangun pesan untuk mencapai tujuan. Teori untuk mendapat kepatuhan oleh Marwell dan Schmitt dalam (Morissan (2003 162): Janji, Ancaman, Menunjukkan keahlian atas hasil positif, Menunjukkan keahlian atas hasil negative, Menyukai, Member duluan. Mengenakan stimuli aversif, Membuat daya tarik moral, Menyatakan perasaan positif, Menyatakan perasaan negatif, Perubahan peran secara positif, Perubahan peran secara negatif. Patuh Karena peduli, Menunjukkan penghormatan positif, Menunjukkan penghormatan negatif.

Dalam Undang-Undang Dasar Nomor 12 tahun 2017 tentang pemilu dijelaskan bahwa pemilihan umum merupakan sarana untuk mewujudkan kedaulatan rakyat dalam pemerintahan Negara Kesatuan Republik Indonesia yang berdasarkan Pancasila, sebagaimana diamanatkan dalam Undang-Undang Dasar Negara Republik Indonesia Tahun 1945. Pemilihan umum mempunyai tiga fungsi utama, yaitu sebagai: Sarana memilih pejabat publik, Sarana pertanggungjawaban pejabat publik, dan Sarana pendidikan politik rakyat. Pemilihan umum Legislatif menjadi sarana untuk menyalurkan aspirasi rakyat. Kondisi kehidupan rakyat yang cenderung berubah memerlukan adanya mekanisme yang mewadahi dan mengaturnya yaitu melalui proses pemilihan umum.

Adapun perolehan kursi golkar dari pemilu legislatif 2004 sampai dengan pemilu legislatif 2019, golkar konsisten dalam mendapatkan kepercayaan dari pemilih di kabupaten aceh tengah, golkar mendapatkan 4 kursi dalam pemilu legislatif tahun 2004, kondisi ini, tidak terlepas dari eletabilitas partai golkar yang masih di percaya masyarakat aceh tengah. Pada pemilu legislatif tahun 2014 kursi di perburuk dengan golkar hanya mendapatkan 3 kursi DPRK Aceh Tengah, dapat dilihat dati tabel di bawah ini:

Tabel 1.1

Jumlah perolehan kursi partai golkar pemilu legislatif Aceh Tengah

\begin{tabular}{|c|c|c|}
\hline \multicolumn{3}{|c|}{ Jumlah Perolehan Kursi partai Golkar } \\
\hline 2004 & $\mathbf{2 0 0 9}$ & $\mathbf{2 0 1 4}$ \\
\hline 4 & 4 & 3 \\
\hline
\end{tabular}

Sumber: Dokumentasi Partai Golkar

Pemilu di Aceh Tengah menghadapi tantangan luar biasa, dimana partisipasi publik terhadap pemilu legislatif naik turun dari setiap pemilu legeslatif di aceh tengah dapat di lihat dari tabel dibawah ini:

Tabel 1.2

Tingkat partisipasi pemilih pemilu legislatif

\begin{tabular}{|c|c|c|}
\hline \multicolumn{3}{|c|}{ Partisipasi publik terhadap pemilu legislatif } \\
\hline 2004 & 2009 & 2014 \\
\hline $84 \%$ & $71 \%$ & $87 \%$ \\
\hline
\end{tabular}

Sumber: Diolah Penulis

Dari tabel diatas bahwa, yang menjadi tantangan terbesar setiap partai politik adalah mendorong partisipasi masyarakat dalam penggunaan hak pilih pada pemilu legislatif tahun 2019. Berkaca dari pengalaman pemilu di aceh tengah, sejak Pemilu 2004 hingga 2014, terjadi penurunan partisipasi pemilih cukup signifikan. Tingkat partisipasi terus menurun dari 89 persen (\%) pada Pemilu 2004 menjadi 84 persen (\%) di 2004, dan terus menurun saat penyelenggaraan Pemilu 2009, yakni tinggal 71 persen (\%). Secara konsisten rata-rata penurunan dari tiga periode pemilu tersebut sebesar kurang lebih 10 persen (\%). Jika trend ini diikuti maka sangat mungkin Pemilu 2019 tingkat partisipasinya tinggal 60 persen (\%). Selain menurunnya angka partisipasi pada 3 periode pemilu, jumlah suara tidak sah juga terus mengalami kenaikan dari 3.3 persen (\%) pada Pemilu 1999 menjadi 9.7 persen(\%) pada Pemilu 2004, dan melonjak pada angka 14.4 persen (\%) di Pemilu 2009. (edy, jurnal lentera, 15, 2015: 13)

Adapun kajian terdahulu dari Penelitian ini adalah, (Sari : 2009) Strategi komunikasi politik PDI per- 
juangan pada pemilihan legislatif tanjung pinang tahun 2009" komunikasi politik merupakan hal yang penting dalam mewujudkan tujuan utama politik terutama partai PDI Perjuangan Kota Tanjungpinang, mengingat tingkat kompetisi yang tinggi pada Pemilu 2009 di Tanjungpinang ini. Metode komunikasi politik ini digunakan PDI Perjuangan dimaksudkan untuk membantu partai politik atau calon legislatif untuk lebih efisien dan efektif membangun hubungan dua arah dengan konstituen mereka. Melalui penerapan strategi komunikasi politik, rakyat dapat mengetahui apakah dukungan, aspirasi dan pengawasan itu tersalur atau tidak dalam berbagai kebijakan publik. Semakin kuatnya konsep strategi komunikasi politikini tak lain karena menguatnya demokrasi di Indonesia. Tujuan penelitian adalah untuk mengetahui strategi komunikasi politik PDIP pada pemilihan legislatif tanjungpinang tahun 2009.

Dalam penelitian ini jumlah Informan sebanyak 10 orang yang berasal dari pengurus DPC Partai PDI Perjuangan Kota Tanjungpinang serta masyarakat atau simpatisan, dan metode yang penulis gunakan adalah metode kualitatif dengan tekhnik pengumpulan data secara wawancara atau interview, pengumpulan data dengan dokumen, untuk menganalisa Strategi Komunikasi Politik PDI Perjuangan pada Pemilihan.

Legislatif Kota Tanjungpinang tahun 2009. Pada Pemilihan legislatif tahun 2009 PDI Perjuangan Kota Tanjungpinang memiliki strategi komunikasi politik yang baik, dengan menjalin komunikasi dengan seluruh unsur kekuatan politik seperti ormas, lembaga-lembaga kemahasiswaan serta melakukan penguatan terhadap komunikasi massa. Strategi komunikasi yang bersumber dari pusat, daerah, maupun strategi caleg yang diusung PDI Perjuangan Kota Tanjungpinang ini dilakukan guna memenangkan pada pemilu legislatif tahun 2009 lalu."

Adapun rumusan masalah dalam Penelitian ini adalah Bagaimana Strategi Komunikasi Politik DPD Partai Golkar Dalam Pemilu Legislatif 2019 di Kabupaten Aceh Tengah. Sedangkan tujuannya untuk strategi komunikasi politik dpd partai golkar pada pemilu legislatif aceh tengah 2019.

Sedangkan teori dalam Penelitian ini,

menggunakan beberapa teori yang relevan sesuai dengan kajian dalam Penelitian ini, sebagai berikut: Menurut Widjaja (2008.1) Komunikasi adalah hubungan kontak antar dan antara manusia baik individu maupun kelompok. Komunikasi adalah inti semua hubugan sosial, apabila orang telah mengadakan hubungan tetap, maka system komunikasi yang mereka lakukan akan menentukan apakah system tersebut dapat mempererat atau mempersatukan mereka, mengurangi ketegangan atau melenyapkan persengketaan apabila muncul. Dalam Damsar (2010:10-11) Politik berasal dari bahasa yunani, yaitu polis yang berarti kota, negara kota. Dari polis berkembang konsep polites yang bermakna warga negara dan konsep Politikus yang berarti kewarganegaraan.

Dari penjelasan etimologis tersebut maka dapat disimpulkan bahwa politik sebagai sesuatu yang berhubungan antara warga negara pada suatu (negara) kota. Secara umum komunikasi politik diartikan oleh Anwar Arifin (2014:57) sebagai pembicaraan dan tindakan untuk memengaruhi manusia dalam kehidupan bermasyarakat dan bernegara. Budiardjo (2008:160) juga menjelaskan bahwa Partai politik adalah suatu kelompok yang teroganisir yang anggotanya memiliki orientasi, nilai-nilai dan cita-cita yang sama. Tujuan kelompok ini adalah untuk memperoleh kekuasaan politik dan merebut kedudukan politik untuk melaksanakan kebijaksanaan kebijaksanan mereka.

\section{METODE}

Pendekatan penelitian yang dipergunakan dalam penulisan ini yaitu pendekatan Penelitian kualitatif deskriptif Adapun penelitian Deskriptif empiris mencakup penelitian terhadap sistematika Strategi Komunikasi Politik Dewan Pimpinan Daerah Partai Golkar, penelitian terhadap taraf strategi komunikasi Politik, penelitian kepustakaan adalah penelitian yang dilakukan dengan meneliti bahan pustaka yang ada, yaitu bahan Strategi Komunikasi Politik Dewan Pimpinan Partai Golkar Primer, bahan Strategi Komunikasi Politik sekunder, dikaji kemudian ditarik suatu kesimpulan dalam hubungannya dengan masalah yang diteliti. Adapun objek penelitian ini mengenai Strategi DPD partai golkar dalam pemilu legislatif 2019. 


\section{HASIL PENELITIAN}

\section{Strategi DPD Partai Golkar Pemilu Legilatif 2019}

Bersumber dari dokumentasi musyawarah daerah partai golkar kabupaten Aceh Tengah menguraikan bahwa pemenangan pemilu legislatif 2019 merupakan agenda utama yang memerlukan penyusuan strategi dan langkah-langkah secara sistematis dengan program yang jelas dan terukur. Hal ini penting karena posisi Partai Golkar di tingkat kabupaten berada diluar pemerintahan. Untuk itu diperlukan langkah-langkah sebagai berikut: 1. Menyusun dan memantapkan rencana operasi pemenangan Pemilu Legislatif. 2. Menyusun pola dan metoda pembinaan serta penggalangan masyarakat yang lebih terarah dan terpadu. 3. Membentuk badan pemenangan pemilu legislatif 2019. 4. Menyusun dan memantapkan kriteria penentuan calon legislatif pada semua tingkatan. 5. Menyusun dan memantapkan pendidikan untuk calon legislatif. 6. Upaya pengkajian dan analisis terhadap perikaraan perkembangan keadaan dalam lima tahun kedepan. 7. Menyusun dan mengevaluasi peta politik nasional daerah. 8. Memantapkan fungsi dan peran organisasi lembaga Pemenangan Pemilu Partai Golkar. 9. Memenangkan Pemilu Legislatif 2019. Strategi DPD partai Golkar dalam memenangkan Pemilu Legislatif 2019.

"pimpinan harian DPD partai Golkar Muhammad Ibrahim, Partai Golkar memiliki kepemimpinan yang terstruktur dengan baik. Partai Golkar yang mempunyai struktur kepengurusan di tingkat Kabupaten, kecamatan, dan desa yang terdiri dari unsur pengurus harian dan bidang-bidang dalam memimpin organisasi baik di tingkat kabupaten maupun ditingkat kecamatan, desa tetap berpedoman kepada anggaran dasar ADRT (Anggaran Dasar Rumah Tangga) dan komunikasi antara bidang selalu berjalan baik yang dilakukan dengan musyawarah dan mufakat.(Wawancara, tanggal 14 Oktober 2018)"

Partai Golkar sangat termotivasi dan mempunyai misi untuk memenangkan Pemilu Legislatif 2019. Salah satu langkah yang dijalankan pimpinan daerah adalah dengan memberikan bimbingan hingga ke pim- pinan desa untuk menarik partisipasi masyarakat. Dalam rangka pemenangan pemilu 2019 yang lalu berdasarkan daerah pemilihan ujung tombak kecamatan dan desa tetap akan kami berikan arahan dan bimbingan untuk memenangkan Partai Golkar dan disamping itu bidang pemenangan pemilu sangat berperan untuk menarik partisipasi masyarakat karena suara golkar adalah suara rakyat, dalam melaksanakan kegiatan pemenangan pemilu, tim Golkar merumuskannya dalam rapat Pleno, membahas tentang persiapan ADM dan keuangan Partai Golkar dalam menghadapi Pemilu Legislatif 2019.

"wawancara peneliti dengan Sekretaris Partai Golkar. Rapat pleno dilakukan setiap 6 bulan sekali. Dalam pemilu 2019 DPD II Partai Golkar Aceh Tengah memenuhi semua persyaratan sebagai peserta Pemilu kepada KPU atau KIP Aceh Tengah seperti: Identitas Anggota Partai, Struktur kepengurusan mulai dari desa sampai Kabupaten, Perekrutan anggota calon legislatif melalui pimpinan kecamatan, Pembekalan kepada calon anggota legislatif. (Wawancara, tanggal 15 Oktober 2018)"

Dalam menghadapi pemilu legislatif 2019, Partai Golkar juga mempersiapkan keuangan untuk mendukung kegiatan partai.

Ada beberapa sumber keuangan Partai untuk biaya Pemilu Legislatif 2019. Atas partisipasi pengurus DPD II pembiayaan kegiatan partai Golkar mendukung setiap kegiatan. sumber keuangan yang didapatkan untuk biaya Pemilu Legislatif 2019 berasal dari; Sumbangan tidak mengikat (sukarela), Bantuan pimpinan pusat partai Golkar, Bantuan pemerintah daerah dalam bentuk pembinaan Partai, Berbentuk iuran dari anggota DPRK Aceh Tengah.

"Keuangan Partai digunakan untuk berbagai kegiatan kampanye seperti: Penggunaan konsolidasi organisasi, Bantuan sewa gedung untuk secretariat pengurus Kecamatan, Untuk biaya kampanye, Pengadaan atribut partai, Biaya administrasi, Biaya transportasi sekretariat Partai Golkar, Honor Staff.

Pada saat Musda atau Musyawarah Daerah 
Keuangan Partai di pertanggungjawabkan. (wawancara, tanggal 16 Oktober 2018)"

Strategi Komunikasi Politik Dewan Pimpinan daerah partai golkar dalam Pemilu Legislatif 2019 dilakukan sesuai dengan memperhatikan kebutuhan masyarakat dan memperjuangkanya.

Dengan cara memperhatikan kebutuhan masyarakat dan berusaha mewujudkannya melalui pemerintahan atasan melalui DPD 1 partai Golkar dan DPP Partai golkar pusat memperjuangkan kebutuhan masyarakat yang selama ini belum tertampung.

"Menurut bagian pemenangan pemilu legislatif Kabupaten Aceh Tengah 2019 Strategi yang dilakukan tim sukses untuk melakukan pendekatan pada masyarakat antara lain: Proses rekrut Caleg, Mengadakan silaturahmi, Mengadakan pembinaan kepada generasi muda , Menampung aspirasi yang disampaikan langsung dari masyarakat. Untuk melakukan sosialisasi pada masyarakat, pimpinan Partai Golkar membentuk tim mulai dari tingkat kecamatan kota hingga ke desa-desa untuk menyampaikan pesan politik pada masyarakat dalam rangka menarik simpati masyarakat.” (Wawancara Tanggal 12 Januari 2019)

Dalam menghadapi Pemilu 2019 yang penuh dengan persaingan membuat masyarakat kebingungan dalam memilih. Namun partai golkar terus bertahan hingga mencapai kemenangan yang gemilang. Dalam hal ini ternyata partai Golkar memiliki strategi yang tetap berusaha menampung dan merealisasikan aspirasi rakyat sehingga rakyat masi tetap percaya pada kepemimpinan partai Golkar. Meyakinkan kembali masyarakat bahwa suara Golkar adalah suara rakyat da anggota DPR yang ada di tingkat pusat ataupun di daerah tetap berusaha memenuhi aspirasi masyarakat.

Pesan yang disampaikan Partai Golkar saat kampanye, Bahwa partai Golkar tetap mengutamakan kepentingan rakyat. Dalam menyampaikan pesan politik, partai golkar menggunakan beberapa strategi dan media. Media sangatlah penting dalam menyampaikan pesan politik dalam skala besar yang tidak terhambat tempat dan waktu.
Oleh karena itu penggunaan media di gunakan oleh Partai Golkar supaya pesan politik dapat tersampaikan merata ke penjuru desa.

Tujuan dari semua strategi dan komunikasi yang dijalankan adalah mendapatkan respon positif dari masyarakat. Berikut jawaban bagian pemenangan pemilu tentang tanggapan masyarakat terhadap pendekatan komunikasi politik dari partai Golkar. Hingga saat ini masyarakat masih menaruh kepercayaan besar/ simpatisan kepada Partai Golkar. Dari deskripsi diatas menunjukkan bahwa strategi komunikasi politik Partai Golkar sagat terorganisir mulai dari pimpinan pusat sampai pada para kader di pedesaan. Sehingga penyampaian pesan politik merata hingga ke penjuru Desa. Komitmen Partai Golkar yang mendengarkan dan menyampaikan aspirasi rakyat membuat rakyat tetap mempercayakan kepemimpinan pada Partai Golkar. Administrasi dan keuangan yang mendukung juga turut andil dalam pemenangan pemilu legislatif 2019.

Dalam menghadapi pemilu legislatif 2019 sudah pasti tentu terdapat kendala yang ringan maupun berat yang harus dihadapi partai Golkar. Munculnya banyak partai membuat masyarakat bingung untuk memilih. Kader yang dahulunya berada di bawah naungan Partai Golkar ada beberapa orang yang berpindah partai dan ada pula yang membentuk partai baru. Sehingga kepercayaan masyarakat menjadi terpecah menjadi beberapa partai yang sama berkualitasnya. Hal tersebut dijabarkan oleh Ketua Harian Partai Golkar.

"Sejak berdirinya partai golkar cukup jaya baik tingkat pusat maupun tingkat daerah namun terakhir ini pengurus dari partai Golkar dari pusat sampai daerah ada yang berpindah ataupun mendirian partai baru, hal inilah yang merupakan kendala Partai Golkar dalam pemilu 2019. Masyarakat menjadi bingung memberikan pilihan terhadap kandidat yang terpecah menjadi beberapa Partai. (wawancara pada tgl 13 Januari 2019)".

Kendala-kendala yang dihadapi Partai Golkar saat melakukan komunikasi pada masyarakat juga dijelaskan oleh sekretaris partai Golkar sebagai berikut: Rendahnya pemahaman masyarakat tentang politik. Budaya masyarakat yang tidan mengacu pada visi misi partai golkar. Masyarakat lebih tertarik pada manipu- 
lasi politik yang lebih memberi janji-janji yang tidak pasti dan politik uang. Oleh karena itu masyarakat menjadi tidak lagi mendengar visi misi partai yang disampaikan. Hal ini menjadi kendala besar partai dalam menjalin komunikasi pada masyarakat.

"Bagian pemenangan pemilu yang terjun langsung ke lapangan mengungkapkan bahwa kendala yang dihadapi adalah "Sebagian besar masyarakat kurang tertarik pada kegiatan politik" Sehingga saat diadakan pertemuan masyarakt tidak datang. Pesan politik yang disampaikan melalui media radio, cetak maupu pamphlet dan baleho tidak digubris oleh mereka. Sifat masyarakat yang seperti itu menghambat masukya pesan yang disampaikan.

Berdasarkan pengamatan peneliti sendiri, kendala yang dihadapi setiap partai adalah, masyarakat yang lebih memilih kerabat dekat yang mencalonkan diri. Sehingga mereka merasa tidak lagi perlu mendengarkan visi misi partai lain. Hal ini juga menjadi kendala bagi partai Golkar dalam mendekati masyarakat melalui strategi dan media komunikasi apapun.

Karena masyarakat tidak lagi mendengarkan, bahkan ada pula masyarakat yang tidak mau lagi berkomunikasi denga partai lain, Karena mereka telah menetapkan pilihan.

\section{Pemilu Legislatif 2019 Kabupaten Aceh Tengah}

Pelaksanaan Pemilu Legislatif 2019 di Aceh Tengah di adakan pada 4 daerah pemilihan. Partai Golkar menyalonkan kandidat terbaiknya di setial daerah pemilihan. Berikut daftar Nama Calon Angota DPRD Kabupaten Aceh Tengah dari Partai Golkar pada setiap daerah pemilihan.

\section{Table 1.1 Daftar Nama Caleg Golkar Daerah Pemilihan 1}

\begin{tabular}{|c|l|}
\hline No & \multicolumn{2}{|c|}{ Nama } \\
\hline 1 & Ansari, SE \\
\hline 2 & Takwa, S.H \\
\hline 3 & Farah Diba \\
\hline 4 & Syafrudin Hakim \\
\hline 5 & Afini Juliana \\
\hline 6 & Lahmudin \\
\hline 7 & Emalda \\
\hline
\end{tabular}

Tabel di atas adalah nama-nama calon yang mewakili Partai Golkar untuk Daerah pemilihan 1 yang meliputi daerah Kecamatan Lut Tawar, Bintang dan Kebayakan.

\section{Table 1.2 Daftar Nama Caleg Golkar} Daerah Pemilihan 2

\begin{tabular}{|c|l|}
\hline No & \multicolumn{1}{|c|}{ Nama } \\
\hline 1 & Ansaruddin Syarifuddin Naldin \\
\hline 2 & Thaib Wadji \\
\hline 3 & Rusmawati \\
\hline 4 & Musnadi \\
\hline 5 & Mulia Kurniawan \\
\hline 6 & Desi Sabatina \\
\hline 7 & Nuria zalna Laila \\
\hline
\end{tabular}

Tabel di atas adalah nama-nama calon yang mewakili Partai Golkar untuk Daerah pemilihan 2 yang meliputi daerah Pegasing, Linge, Bebesen, Bies, Kute Panang, Jagong Jeget dan Atu Lintang.

Table 1.3 Daftar Nama Caleg Golkar Daerah Pemilihan 3

\begin{tabular}{|c|l|}
\hline No & \multicolumn{2}{|c|}{ Nama } \\
\hline 1 & Drs. Zulkifli \\
\hline 2 & Hasbullah \\
\hline 3 & Nuraini Simahbengi \\
\hline 4 & Mukhlis \\
\hline 5 & M. Aris \\
\hline 6 & Lisna Dewi \\
\hline 7 & Abdansyah \\
\hline 8 & Nuriana \\
\hline
\end{tabular}

Tabel di atas adalah nama-nama calon yang mewakili Partai Golkar untuk Daerah pemilihan 3 yang meliputi daerah Kecamatan Silihnara, Ketol, Rusip Antara dan Celala

\section{Table 1.4 Daftar Nama Caleg Golkar Daerah Pemilihan 4}

\begin{tabular}{|c|l|}
\hline No & \multicolumn{1}{|c|}{ Nama } \\
\hline 1 & Muchsin Hasan \\
\hline 2 & Yusri Hasan \\
\hline 3 & Susi Fitri Arita \\
\hline 4 & Abu Bakar \\
\hline 5 & Islamudin \\
\hline 6 & Zaharni \\
\hline 7 & Eva Amalia \\
\hline 8 & Zuhri Andy \\
\hline
\end{tabular}

Sumber: Dokumentasi Partai Golkar pada 2019 
Tabel di atas adalah nama-nama calon yang mewakili Partai Golkar untuk Daerah pemilihan 4 yang meliputi daerah Kecamatan Bebesen, Bies dan Kute Panang.

Beberapa tabel diatas menunjukkan namanama Calon Legislatif yang di tersebar di beberapa daerah pemilihan. Calon-calon tersebut kemudian berkomunikasi pada masyarakat di daerah pemilihan tersebut untuk mendapatkan dukungan masyarakatdan dapat memenangkan Pemilihan Umum.

\section{Daftar Calon Terpilih Anggota DPRK Aceh Tengah} 2019

Setelah dilaksanakan pemilihan umum Legislatif DPRK Aceh Tengah didapatkan hasil suara. Calon yang memperoleh suara terbanyak atau mencapai suara minimal yang lolos menjadi anggota DPRK. Berikut nama-nama calon yang terpilih pada Pemilu Legislatif DPRK Aceh Tengah dari berbagai Partai yang berpartisipasi.

\section{Tabel 2.1 Daftar Calon Terpilih Daerah Pemilihan 1}

\begin{tabular}{|c|l|l|l|c|}
\hline No & \multicolumn{1}{|c|}{$\begin{array}{c}\text { Partai } \\
\text { Politik }\end{array}$} & $\begin{array}{c}\text { Nama } \\
\text { Calon } \\
\text { Terpilih }\end{array}$ & $\begin{array}{c}\text { Suara } \\
\text { Sah }\end{array}$ & $\begin{array}{c}\text { Pering- } \\
\text { kat } \\
\text { Suara }\end{array}$ \\
\hline $\mathbf{1}$ & Gerindra & $\begin{array}{l}\text { Eka Sapu- } \\
\text { tra }\end{array}$ & 1.399 & 1 \\
\hline $\mathbf{2}$ & PDI P & $\begin{array}{l}\text { Arwin } \\
\text { Mega }\end{array}$ & 2.205 & 1 \\
\hline $\mathbf{3}$ & Golkar & $\begin{array}{l}\text { Muchsin } \\
\text { Hasan }\end{array}$ & 2.074 & 1 \\
\hline $\mathbf{4}$ & Nasdem & Hamdan & 1.554 & 1 \\
\hline $\mathbf{5}$ & PAN & Salman & 1.790 & 1 \\
\hline $\mathbf{6}$ & PKS & Muzakir & 878 & 1 \\
\hline $\mathbf{7}$ & Hanura & $\begin{array}{l}\text { Abadi } \\
\text { Ayus }\end{array}$ & 630 & 1 \\
\hline $\mathbf{8}$ & $\begin{array}{l}\text { Demo- } \\
\text { krat }\end{array}$ & $\begin{array}{l}\text { Syukurdi } \\
\text { Iska }\end{array}$ & 1.205 & 1 \\
\hline
\end{tabular}

Tabel 2.2 Daftar Calon Terpilih Daerah Pemilihan 2

\begin{tabular}{|c|l|l|c|c|}
\hline $\begin{array}{c}\text { N } \\
0\end{array}$ & $\begin{array}{c}\text { Partai } \\
\text { Politik }\end{array}$ & $\begin{array}{c}\text { Nama Calon Ter- } \\
\text { pilih }\end{array}$ & $\begin{array}{c}\text { Suara } \\
\text { Sah }\end{array}$ & $\begin{array}{c}\text { Per- } \\
\text { ingkat } \\
\text { Suara }\end{array}$ \\
\hline 1 & PKB & $\begin{array}{l}\text { Muhammad Abdi } \\
\text { Nasution }\end{array}$ & 1.456 & 1 \\
\hline 2 & $\begin{array}{l}\text { Gerin- } \\
\text { dra }\end{array}$ & Edi Kurniawan & 1.453 & 1 \\
\hline
\end{tabular}

\begin{tabular}{|c|l|l|c|c|}
\hline 3 & PDI P & Jihar Firdaus & 1.712 & 2 \\
\hline 4 & PDI P & $\begin{array}{l}\text { Suryati } \\
\text { WAAS }\end{array}$ & 2.172 & 1 \\
\hline 5 & GOLKAR & $\begin{array}{l}\text { Ansaruddin S } \\
\text { Naldin }\end{array}$ & 1.110 & 1 \\
\hline 6 & PAN & $\begin{array}{l}\text { Ilhamuddin, } \\
\text { S.Hut }\end{array}$ & 1.839 & 1 \\
\hline 7 & Nasdem & Joharsyah & 1.528 & 1 \\
\hline
\end{tabular}

Table 2.3 Daftar Calon Terpilih Daerah Pemilihan 3

\begin{tabular}{|c|l|l|c|c|}
\hline No & $\begin{array}{c}\text { Partai } \\
\text { Politik }\end{array}$ & $\begin{array}{c}\text { Nama } \\
\text { Calon Ter- } \\
\text { pilih }\end{array}$ & $\begin{array}{c}\text { Suara } \\
\text { Sah }\end{array}$ & $\begin{array}{c}\text { Pering- } \\
\text { kat } \\
\text { Suara }\end{array}$ \\
\hline $\mathbf{1}$ & PKB & GIMIN & 1.903 & 1 \\
\hline $\mathbf{2}$ & PDI P & Samsuddin & 1.995 & 1 \\
\hline $\mathbf{3}$ & Golkar & Mukhlis & 1.398 & 1 \\
\hline $\mathbf{4}$ & $\begin{array}{l}\text { Gerin- } \\
\text { dra }\end{array}$ & Muhammad & 830 & 1 \\
\hline $\mathbf{5}$ & $\begin{array}{l}\text { Demo- } \\
\text { krat }\end{array}$ & Termina & 1.486 & 1 \\
\hline $\mathbf{6}$ & PKS & Susilawati & 1.330 & 1 \\
\hline $\mathbf{7}$ & PPP & Fauzan & 707 & 1 \\
\hline $\mathbf{8}$ & $\begin{array}{l}\text { Partai } \\
\text { Aceh }\end{array}$ & Ismail & 1.209 & 1 \\
\hline
\end{tabular}

Tabel 2.4 Daftar Calon Terpilih Daerah Pemilihan 4

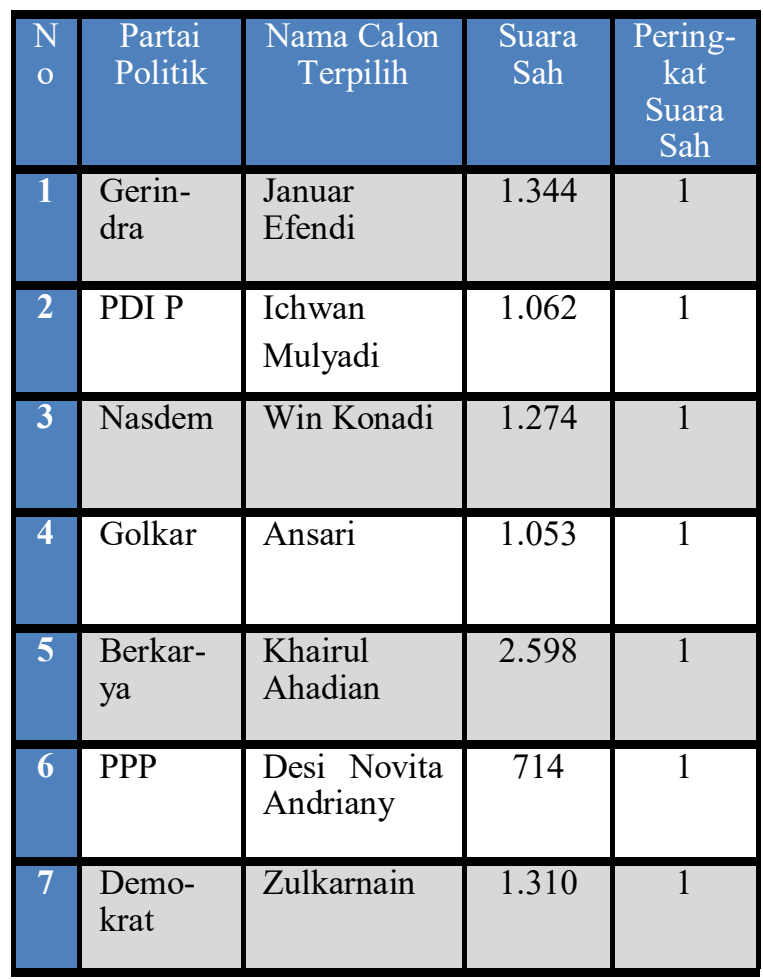

Sumber: Dokumentasi KIP Aceh Tengah 2019 
Tabel diatas diatas adalah hasil rekaputilasi suara yang menentukan pemenang Pemilu Legislatif anggota DPRK Aceh Tengah. Itu berarti nama-nama diatas adalah anggota DPRK Aceh Tengah periode 2019-2024.

\section{Hasil Perolehan Suara Partai Golkar}

Berdasarkan hasil rekapitulasi suara yang menetapkan pemenang dari berbagai Partai, berikut penulis merangkum hasil rekapitulasi suarauntuk Partai Golkar khususnya.

Table 3.1 Hasil Perolehan Suara Partai Golkar

\begin{tabular}{|c|c|c|}
\hline $\begin{array}{c}\text { Daerah } \\
\text { Pemilihan }\end{array}$ & $\begin{array}{c}\text { Jumlah } \\
\text { Perolehan } \\
\text { Suara }\end{array}$ & $\begin{array}{c}\text { Jumlah } \\
\text { Perolehan } \\
\text { Kursi }\end{array}$ \\
\hline 1 & 3.799 & 1 \\
\hline 2 & 1.919 & 1 \\
\hline 3 & 3.506 & 1 \\
\hline 4 & 4.411 & 1 \\
\hline
\end{tabular}

Sumber: Dokumentasi partai Golkar tahun 2019

Dari tabel diatas dapat kita simpulkan bahwa Partai Golkar berhasil meraih 4 kursi DPRK. Keberhasilan ini tak luput dari pendekatan kader Partai Golkar yang menjalin komuniksi politik yang baik pada masyarakat. Sehingga masyarakat menaruh kepercayaan pada kandidat dari Partai Golkar.

\section{KESIMPULAN}

Strategi komunikasi politik yang diterapkan partai Golkar dalam pemilu legislatif ialah komunikasi yang terstruktur dari pimpinan pusat hingga kader di pedesaan sehingga pesan politik dapat tersampaikan secara merata, di dalam menghadapi pemilu legislatif tahun 2019, golkar memberikan informasi kepada masyarakat yang mempunyai hak pilih ataupun belum mempunyai hak pilih, mendidik masyarakat, menampung aspirasi masyarakat, dan mensosialisasikan yang ditujukan untuk pemerintah dah lembaga-lembaga politik lainnya maka dapat disimpulkan bahwa dalam menghadapi pemilu legislati tahun 2019 Aceh Tengah, ada insiatif dan berbagai cara dari pengurus DPD Gol- kar agar untuk menyampaikan segala bentuk programkerja kepada masyarakat, sabagai alat komunikasi politik partai seperti memberikan informasi kepada media masa, Dan kendala yang dihadapi adalah masyarakat yang tidak menerima pesan dan tidak mau berkomunikasi dengan kader partai Golkar dikarenakan tidak tertarik pada kegiatan politik ,masyarakat yang lebih tertarik pada manipulasi politik dan masyarakat yang sudah memliki kandidat dari kerabat dekat.

\section{DAFTAR PUSTAKA}

Anwar, Arifin (2014). Perspektif Ilmu Politik . Jakarta: Pustaka

Indonesia.

Arni, Muhammad (2009). Komunikasi Organisasi. Ja karta: Bumi Aksara

Budiarjo, Miriam (2008). Dasar-Dasar Ilmu Politik (edisi revisi). Jakarta: PT Media Pustaka Utama. Cangara, Hafied (2009). Komunikasi Politik (Konsep, Teori, Strategi). Jakarta : Rajawali Press. Damsar (2010). Pengantar Sosiologi Politik. Jakarta: Kencana Prenada Media Group. Haris, Syamsuddin dkk (2014). Pemilu Nasional Seren tak 2009 (Position Paper). Jakarta: Electoral Institute

LIPI.

Harun, Rochajat dan Sumarno (2006). Komunikasi Politik Sebagai Suatu Pengantar. Bandung: Mandar

Maju.

Morissan (2003). Teori Komunikasi Individu Hingga Massa. Jakarta: Kencana Prenada Media Group.

Pawito (2007). Penelitian Komunikasi Kualitatif. Yog yakarta: Pelangi Aksara.

Rakhmad, Jalaludin (2003). Psikologi Komunikasi. Bandung: PT Remaja Rosdakarya.

Rush, Michael dan Phillip Althof (2007). Pengantar Sosiologi Politik. Jakarta: PT Raja Grafindo Persada

Surbakti, Ramlan (1999). Memahami Ilmu Politik. Ja karta: Gramedia Widiasarana Indonesia Suyanto, Bagong dan Sutinah (2005). Metode Penelitian Sosial: Berbagai Altrnatif Pendeka tan. Jakarta: Kencana Prenada Media Group. Sugiyono (2005). Metode Penelitian Kualitatif. Ban dung:

Alfabeta. 
Varma (2001). Teori Politik Modern. Jakarta: PT Raja Grafindo Persada.

Vivian, John (2008). Teori Komunikasi Massa. Jakarta:
Kencana
Prenada
Media
Group.

Widjaja (2008). Komunikasi dan Hubungan Masyara kat. Jakarta: Bumi Aksara

Materi 2018 Musyawarah Daerah-VIII Partai Golongan Karya Kabupaten Aceh Tengah.

Materi Pendidikan dan Latihan Kader. Penggerak Terit orial Desa Lembaga Pengelola Kaderisasi De wan Pimpinan Pusat Partai Golkar 